Piotr Daszkiewicz

Instytut Historii Nauki im. L. i A. Birkenmajerów PAN

Philippe Edel

Strasburg

\title{
EGZEMPLARZ ANATOME TESTUDINIS EUROPAE ZE ZBIORÓW BIBLIOTEKI WRÓBLEWSKICH W WILNIE - - INTERESUJĄCY DOKUMENT HISTORII NAUKI
}

W ramach inwentaryzacji ${ }^{1}$ zachowanych egzemplarzy Anatome Testudinis Europae, pracy Ludwika-Henryka Bojanusa (1776-1827), autorzy odwiedzili 9 listopada 2017 Bibliotekę Wróblewskich w Wilnie ${ }^{2}$. Wizyta miała miejsce w związku z wydaniem litewskiej wersji biografii L.-H. Bojanusa ${ }^{3}$. Biblioteka Wróblewskich posiada dwa egzemplarze oryginalnego wydnia Anatome Testudinis Europae, trzeci egzemplarz, prawdopodobnie niegdyś własność samego L.-H. Bojanusa, przechowywany jest w Muzeum Zoologii, będącym częścią Muzeum Uniwersytetu Wileńskiego.

Oba egzemplarze z Biblioteki Wróblewskich oprawione są razem z kolejną pracą L.-H. Bojanusa, wydanym w 1821 Wilnie Parergon ad L.H. Bojani Anatomen testudinis: cranii vertebratorum animalium, scilicet piscium, reptilium, avium, mammaliium comparationem faciens, icone illustratam: in usum studiosae juventutis seorsum excusum. Jest to rozwiązanie logicznie, albowiem praca ta była przecież uzupełnieniem Anatome Testudinis Europae. Jednakże autorzy po raz pierwszy zetknęli się z podobnym introligatorskim połączeniem obu prac. Oprawa wskazuje, że połączenia tego dokonano niewątpliwie już w XIX w. Nie sposób jednak ustalić czy zrobił to sam L.-H. Bojanus czy też oprawę sporządzono w późniejszym okresie.

${ }^{1}$ Patrz: P. Daszkiewicz, P. Edel: Poszukiwanie egzemplarzy Anatome Testudinis Europae w europejskich i amerykańskich bibliotekach, „Z badań nad książką i księgozbiorami historycznymi" t. 10, 2016 s. 119-130.

${ }^{2}$ Dawniej Państwowa Biblioteka im. Eustachego i Emilii Wróblewskich w Wilnie, obecnie Biblioteka Litewskiej Akademii Nauk.

${ }^{3}$ P. E d e l, P. D a s z k i e w i c z: Liudvigas Heinrichas Bojanus Wilno 2016.

Kwartalnik Historii Nauki i Techniki R. 63: 2018 nr 3 s. 153-154 
Jeden z egzemplarzy przechowywanych z kilku przyczyn jest szczególnie interesującym dla historii nauki dokumentem. Na jego pierwszej stronie figuruje autograf Adama Ferdynanda Adamowicza (1802-1881), wileńskiego profesora, ucznia i następcy, a zarazem jednego z pierwszych biografów L.-H. Bojanusa, wybitnego lekarza, weterynarza i historyka nauki. Zapewne egzemplarz ten był jego własnością. Jest to także unikalny egzemplarz z punktu widzenia historii techniki drukarskiej. Przypomnijmy, że:

Interesującą i dotychczas nieznaną historykom nauki informację udało się otrzymać od niemieckiego herpetologa i kolekcjonera dr. Thomasa Schöttlera, który jest właścicielem egzemplarza z kolorowymi ilustracjami, będącego uprzednio, jak wskazuje stempel, własnością Biblioteki Brytyjskiego Towarzystwa Medycznego (British Medical Association Library). Nie wiadomo jaka część nakładu i dlaczego została wydana z kolorowymi ilustracjami. Zdaniem dr. T. Schöttlera nie ulega wątpliwości, iż chodzi o kolor pochodzący z oryginalnego druku, a nie o ilustracje pokolorowane już po publikacji. Drugi znany „kolorowy” egzemplarz znajduje się w Stanach Zjednoczonych w zbiorach biblioteki uniwersyteckiej (Kenneth Spencer Research Library) w Kansas ${ }^{4}$.

W egzemplarzu przechowywanym w Bibliotece Wróblewskich kolorowa jest tylko jedna ilustracja (Tabula XVIII), a reszta jest czarno-biała. Wskazuje to, że najprawdopodobniej egzemplarz został oprawiony gdy wydrukowana była tylko jedna kolorowa strona, a resztę najprawdopodobniej wydrukowano później. Ponieważ, egzemplarz jest oprawiony wraz z opublikowanym w 1821 r. dziełem Parergon ad L.H. Bojani Anatomen testudinis..., możemy wnioskować, że druk kolorowych rycin rozpoczęto właśnie w tym roku lub później.

W jaki sposób i kiedy egzemplarz trafił do założonej w 1912 r. Państwowej Biblioteki im. Eustachego i Emilii Wróblewskich? Dlaczego nie pozostał w zbiorach rodzinnych A.F. Adamowicza lub nie trafił do zbiorów uniwersyteckich lub Towarzystwa Medycznego Wileńskiego, któremu uczony ten przewodniczył? Jedyną informacją na temat pochodzenia egzemplarza jest zapis na wewnętrznej stronie okładki „od prof. Narębskiego 20 I 1930”. Ta wyjątkowo cenna książka jest zatem darem dla Biblioteki od Stefana Narębskiego (1892-1966), wybitnego architekta i profesora Uniwersytetu Stefana Batorego, a po wojnie Uniwersytetu Mikołaja Kopernika w Toruniu. Niestety nie wiadomo w jakich okolicznościach prof. S. Narębski nabył ten unikalny egzemplarz Anatome Testudinis Europae.

\footnotetext{
${ }^{4}$ P. D a s z ki e wi c z, P. E d el: Poszukiwanie egzemplarzy s. 127.
} 